Eur. J. Clin. Chem. Clin. Biochem.

Vol. 32, 1994, pp. 5-9

(c) 1994 Walter de Gruyter \& Co. Berlin $\cdot$ New York

\title{
Increased Release of Platelet-Derived Growth Factor from Platelets in Chronic Liver Disease
}

\author{
By T. Shiraishi, S. Morimoto, E. Koh, K. Fukuo and T. Ogihara \\ Department of Geriatric Medicine, Osaka University Medical School, Osaka
}

(Received April 15/October 4, 1993)

Summary: The concentrations of platelet-derived growth factor in serum in 7 healthy controls $(61 \pm 9$ years; mean $\pm \mathrm{SD}$ ) and 10 patients (62 \pm 8 years) with chronic liver disease (chronic hepatitis and/or liver cirrhosis) were compared.

The plasma concentration of platelet-derived growth factor was below the detection limit $(<0.45 \mu \mathrm{g} / \mathrm{l})$ in all the subjects studied. The peripheral blood platelet count in patients with chronic liver disease was significantly lower than that in control subjects. However, the concentration of platelet-derived growth factor in serum, which was assumed to be released from platelet, was similar in patients with chronic liver disease and control subjects. These results indicate that the mean amount of platelet-derived growth factor released from the same number $\left(10^{9}\right)$ of platelets, calculated from the serum platelet-derived growth factor concentration and the peripheral blood platelet count, in patients with chronic liver disease $\left(33 \pm 11 \mathrm{ng} / 10^{9}\right.$ platelets $)$ was significantly $(\mathrm{p}<0.01)$ higher than that in control subjects ( $14 \pm 5 \mathrm{ng} / 10^{9}$ platelets).

Moreover, the amount of platelet-derived growth factor released from $10^{9}$ platelets inversely correlated with the serum concentration of pseudocholinesterase activity $(r=-0.65, p<0.01)$, and correlated positively $(r=0.91$, $\mathrm{p}<0.01$ ) with the percent retention of indocyanine green in serum, in all subjects studied.

These findings suggest that the amount of platelet-derived growth factor releasable from platelets of patients with chronic liver disease is higher than that in normal subjects and that it correlates with the severity of the disease. Platelet-derived growth factor released from platelets may be involved in the pathophysiology of chronic liver diseases as a local factor.

\section{Introduction}

Platelet-derived growth factor is a glycoprotein consisting of two polypeptides, A- and B-chains (1). Human platelet-derived growth factor is released from the $\alpha$ granules of platelets $(2-4)$ when platelets aggregate, and is known to promote the proliferation of fibroblasts $(5,6)$, smooth muscle cells (7) and glial cells (8) in vitro. Therefore, human platelet-derived growth factor is thought to participate in wound healing and the development of arteriosclerosis in vivo (9). On the other hand, chronic liver diseases, including chronic hepatitis and liver cirrhosis, are characterized by destruction and de- rangement of lobular architecture and fibrosis (10). Liver fat-storing cells, referred to as vitamin A-containing lipocytes or Ito cells, which are cells of mesenchymal origin situated in the space of Disse, proliferate and produce several matrix components in inflamed liver tissue, and are thought to play a central role in liver fibrogenesis $(11-13)$. Recent studies have shown that platelet-derived growth factor and thrombocyte lysate promote proliferation of cultured fat-storing cells and stimulate synthesis of extracellular matrix, suggesting the participation of platelet-derived growth factor in fibrosis of the liver (14-17). Thrombocytopenia, which 
is frequently seen in chronic liver diseases, has been attributed to hypersplenism (10). Stein \& Harker reported that the life-span of platelets in the peripheral circulation and the number of platelets in chronic liver diseases are decreased, and that the platelets are consumed in the liver (18). We previously reported that the amount of platelet-derived growth factor in the serum of patients with idiopathic thrombocytopenic purpura was lower than that in control subjects, and that it correlated positively with the peripheral blood platelet count. Platelet-derived growth factor released from $10^{9}$ platelets in patients with idiopathic thrombocytopenic purpura was not different from that in control subjects (19). In this study, we measured the platelet-derived growth factor released from platelets in patients with chronic liver diseases, and found that it was increased and correlated with the severity of disease.

\section{Materials and Methods}

\section{Subjects and sample preparation}

The subjects studied consisted of 7 healthy volunteers ( 4 males and 3 females: $61 \pm 9$ years; mean \pm SD) and 10 patients with chronic liver disease (chronic hepatitis and/or liver cirrhosis; 7 males and 3 females; $62 \pm 8$ years). Chronic liver disease was diagnosed on the basis of laboratory biochemical tests including serum levels of aspartate aminotransferase, alanine aminotransferase, albumin, globulin, total bilirubin and pseudocholinesterase, prothrombin time, indocyanine green clearance, serologic tests for hepatitis viruses (hepatitis $B$ virus antigen and hepatitis $C$ virus antibody), and by imaging including ultrasonography, computed tomography, magnetic resonance imaging, radioisotope scanning, and angiography. Indocyanine green clearance was determined by calculation of the indocyanine green retention in the serum 15 min after intravenous injection of indocyanine green at a dose of $0.5 \mathrm{mg} / \mathrm{kg}$ body weight. Hepatitis $\mathrm{C}$ virus antibody was examined by enzymelinked immunosorbent assay (20). None of the subjects had been administered any drugs that would affect platelet function. Blood samples were obtained from these subjects in the morning after an overnight fast. Serum samples were prepared by allowing $5 \mathrm{ml}$ of blood to clot in a glass tube at room temperature for $2 \mathrm{~h}$ followed by separation of serum by centrifugation at $1000 \mathrm{~g}$ for $10 \mathrm{~min}$. Platelet-poor plasma was obtained from blood collected in a plastic syringe containing $4 \mathrm{mmol} / 1$ EDTA and centrifuged at $12000 \mathrm{~g}$ for $10 \mathrm{~min}$ at $4{ }^{\circ} \mathrm{C}$. All these samples were stored at $-20^{\circ} \mathrm{C}$ for later analysis. The content of platelet-derived growth factor did not increase on standing for more than $2 \mathrm{~h}$ or by adding $2 \mu \mathrm{mol} / \mathrm{l}$ adenosine diphosphate.

\section{Platelet-derived growth factor determination}

The platelet-derived growth factor concentration was measured using a double-step competitive radioimmunoassay (RIA) kit (Amersham Co., Bucks, UK). In the RIA the following were used: platelet-derived growth factor B-chain homodimer (c-sis recombinant) labelled with ${ }^{125}$ I as a tracer, platelet-derived growth factor B-chain homodimer (c-sis recombinant) as a standard, a goat antihuman platelet-derived growth factor polyclonal antibody for the first antibody, and donkey anti-sheep antiserum in phosphate-buffered saline with gelatin and $10 \%$ polyethylene glycol for the second antibody. The range of this assay is $0.45-60 \mu \mathrm{g} / \mathrm{l}$.

\section{Statistical analysis}

Statistical analysis was performed using the Wilcoxon rank sum test and correlations were calculated by Spearman's rank test.

\section{Results}

Table 1 shows the clinical and laboratory data of the patients with chronic liver disease. On the basis of the

Tab. 1 Clinical and laboratory data of patients with chronic liver diseases.

\begin{tabular}{|c|c|c|c|c|c|c|c|c|c|c|c|c|}
\hline Case & Age & Sex & $\begin{array}{l}\text { Aspar- } \\
\text { tate } \\
\text { amino- } \\
\text { trans- } \\
\text { ferase } \\
U / l)\end{array}$ & $\begin{array}{l}\text { Alanine } \\
\text { amino- } \\
\text { trans- } \\
\text { ferase } \\
(\mathrm{U} / \mathrm{l})\end{array}$ & $\begin{array}{l}\text { Total } \\
\text { protein }\end{array}$ & Albumin & $\begin{array}{l}\text { Total } \\
\text { bili- } \\
\text { rubin } \\
(\mathrm{mg} / \mathrm{l})\end{array}$ & 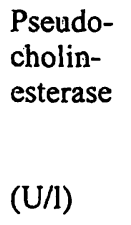 & $\begin{array}{l}\text { Pro- } \\
\text { thrombin } \\
\text { time } \\
\text { (percent } \\
\text { of control) } \\
(\%)\end{array}$ & $\begin{array}{l}\text { Indo- } \\
\text { cyanine } \\
\text { green } \\
\text { clearance } \\
(\%)\end{array}$ & $\begin{array}{l}\text { Haema- } \\
\text { tocrit }\end{array}$ & $\begin{array}{l}\text { Platelet } \\
\text { count }\end{array}$ \\
\hline 1 & 74 & $\bar{\sigma}$ & 112 & 44 & 70 & 35 & 18 & 891 & n. d. & 35 & 0.343 & 30 \\
\hline 2 & 53 & $\hat{\sigma}$ & 122 & 107 & 70 & 39 & 10 & 2404 & 79 & 24 & 0.378 & 39 \\
\hline 3 & 63 & $q$ & 39 & 55 & 62 & 30 & 6 & 1175 & 79 & 28 & 0.363 & 40 \\
\hline 4 & 59 & $\delta$ & 90 & 140 & 78 & 40 & 9 & 1974 & 68 & 24 & 0.448 & 70 \\
\hline 5 & 75 & 우 & 40 & 63 & 76 & 40 & 9 & 2313 & 81 & 19 & 0.402 & 87 \\
\hline 6 & 54 & 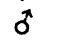 & 41 & 87 & 76 & 47 & 9 & 4381 & 77 & 12 & 0.439 & 120 \\
\hline 7 & 70 & ㅇ & 40 & 35 & 62 & 32 & 10 & 2012 & 76 & 15 & 0.380 & 130 \\
\hline 8 & 60 & 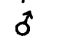 & 33 & 40 & 73 & 42 & 7 & 2279 & 88 & 15 & 0.352 & 150 \\
\hline 9 & 57 & $\delta$ & 39 & 41 & 72 & 39 & 8 & 2843 & 63 & 16 & 0.402 & 150 \\
\hline 10 & 57 & $\sigma^{2}$ & 24 & 27 & 66 & 31 & 6 & 1509 & 60 & 18 & 0.316 & 160 \\
\hline $\begin{array}{l}\text { Mean } \\
\pm S D\end{array}$ & $\begin{array}{r}62 \\
\pm 8\end{array}$ & & $\begin{array}{r}58 \\
\pm 38 \\
\end{array}$ & $\begin{array}{r}64 \\
\pm 36 \\
\end{array}$ & $\begin{array}{r}71 \\
\pm 5 \\
\end{array}$ & $\begin{array}{r}38 \\
\pm 5\end{array}$ & $\begin{array}{r}9 \\
\pm 3\end{array}$ & $\begin{array}{r}2178 \\
\pm 975\end{array}$ & $\begin{array}{r}75 \\
\pm 9\end{array}$ & $\begin{array}{r}21 \\
\pm 7\end{array}$ & $\begin{array}{r}0.382 \\
+0.042\end{array}$ & $\begin{array}{r}98 \\
\pm 51\end{array}$ \\
\hline $\begin{array}{l}\text { Norma } \\
\text { range }\end{array}$ & & & $\begin{array}{r}0 \\
-30\end{array}$ & $\begin{array}{r}0 \\
-32\end{array}$ & $\begin{array}{r}64 \\
-81\end{array}$ & $\begin{array}{r}36 \\
-47\end{array}$ & $\begin{array}{r}3 \\
-14\end{array}$ & $\begin{array}{r}2700 \\
-5600\end{array}$ & $\begin{array}{r}80 \\
-120\end{array}$ & $\begin{array}{r}0 \\
-10\end{array}$ & $\begin{array}{r}0.38 \\
-0.48\end{array}$ & $\begin{array}{r}130 \\
-320\end{array}$ \\
\hline
\end{tabular}
Indocyanine green clearance: percent retention of indocyanine green in sérum 15 minutes after injection of $0.5 \mathrm{mg} / \mathrm{kg}$ body weight, n. d.:
not done. 
results of laboratory biochemical tests and diagnostic imaging, cases $1-5$ and $7-10$ were diagnosed as having liver cirrhosis and case 6 was diagnosed as having chronic hepatitis. In all the patients, chronic liver disease was due to viral hepatitis; hepatitis B in case 6 and hepatitis $C$ in the other cases. The mean platelet count in the peripheral blood of patients with chronic liver disease, which was $98 \pm 51 \times 10^{9} / 1$ (mean $\pm \mathrm{SD}$ ), was significantly $(p<0.01)$ lower than that of the control subjects, which was $211 \pm 42 \times 10^{9} / 1$.

In patients with chronic liver disease, the mean serum platelet-derived growth factor concentration was 4.6 $\pm 1.8 \mu \mathrm{g} / \mathrm{l}$ (range $2.5-9.0 \mu \mathrm{g} / \mathrm{l}$ ); it did not differ significantly from that in the control subjects, which was $5.0 \pm 1.7 \mu \mathrm{g} / 1$ (range 1.9-7.5 $\mu \mathrm{g} / \mathrm{l}$ ) (fig. 1a). The serum platelet-derived growth factor concentration mainly reflects the amount of platelet-derived growth factor released from platelets, because the plasma platelet-derived growth factor concentrations of all the subjects studied were below the detection limit $(<0.45 \mu \mathrm{g} / \mathrm{l})$. The amount of platelet-derived growth factor released from platelets was calculated as follows: the serum platelet-derived growth factor concentration was cor-
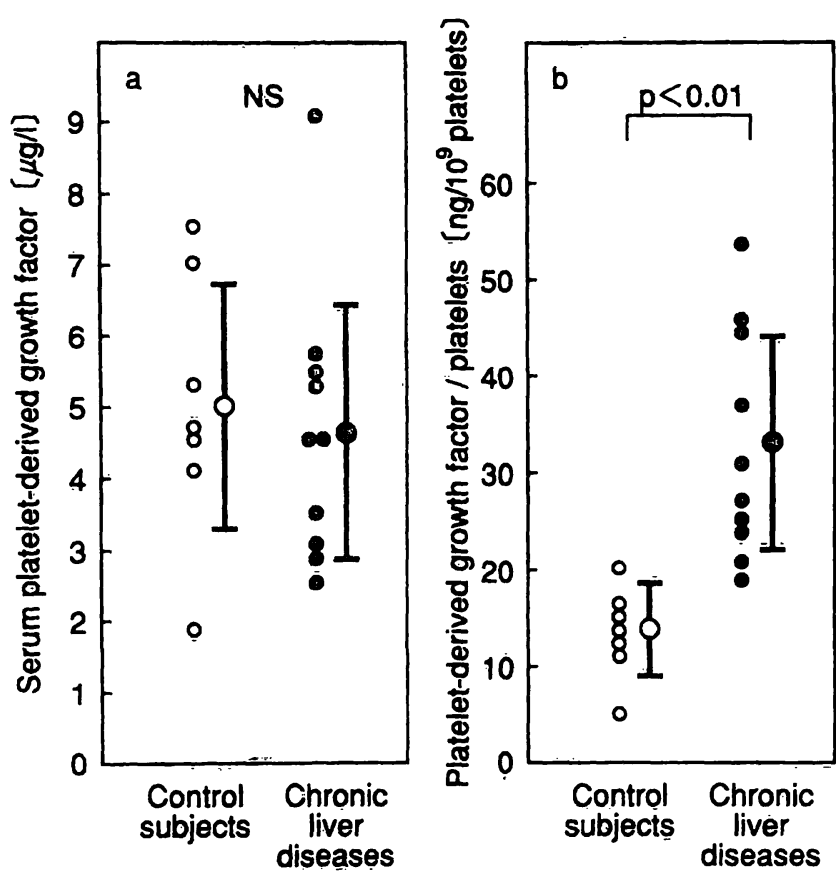

Fig. 1 Comparison of platelet-derived growth factor concentrations in patients with chronic liver disease and in control subjects.

a) Serum. Open circles represent individual values and the mean (large circle) of normal controls, and closed circles represent individual values and the mean (large circle) of patients with chronic liver disease. Vertical bars denote SD. NS = not significant.

b) Released from $10^{9}$ platelets. Serum platelet-derived growth factor concentrations were corrected for the haematocrit and expressed as ng platelet-derived growth factor per $10^{9}$ platelets. Key as in figure la. rected for the haematocrit, divided by the peripheral blood platelet count, and expressed as ng platelet-derived growth factor per $10^{9}$ platelets. The mean amount of platelet-derived growth factor released from the platelets in patients with chronic liver disease, which was $33 \pm 11 \mathrm{ng} / 10^{9}$ cells, was significantly $(\mathrm{p}<0.01)$ higher than that in the control subjects, which was $14 \pm 5 \mathrm{ng} / 10^{9}$ cells (fig. $1 \mathrm{~b}$ ).

The amount of platelet-derived growth factor released from $10^{9}$ platelets correlated inversely with the peripheral blood platelet count $(r=-0.87, p<0.01)$ and serum concentration of pseudocholinesterase activity $(\mathrm{r}=-0.65, \quad \mathrm{p}<0.01)$, and correlated positively $(r=0.91, p<0.01)$ with the percent retention of indocyanine green, in all the subjects studied. There was a negative correlation $(r=-0.87, p<0.01)$ between the peripheral blood platelet count and the percent retention of indocyanine green in the patients with chronic liver disease.

\section{Discussion}

We previously reported that the mean serum plateletderived growth factor concentration was significantly decreased in patients with idiopathic thrombocytopenic purpura, and that there was a significant positive correlation between blood platelet count and serum plateletderived growth factor concentration in the combined group of control subjects and patients with idiopathic thrombocytopenic purpura (19). Platelet-derived growth factor is a local factor, and the clearance rate of plateletderived growth factor in the circulation in vivo is very rapid (21). The concentrations of platelet-derived growth factor in plasma of all normal subjects and in patients with idiopathic thrombocytopenic purpura or chronic liver disease were below the detection limit. The concentrations of platelet-derived growth factor in serum were higher than those in ADP-stimulated plasma (22). These observations suggest that the serum plateletderived growth factor level reflects mainly the amount of platelet-derived growth factor releasable from platelets, and that the platelet-derived growth factor released from the platelets is apparently dependent on the platelet count in the peripheral blood in patients with idiopathic thrombocytopenic purpura and normal subjects. The amount of platelet-derived growth factor releasable from the same number of platelets was not significantly different between patients with idiopathic thrombocytopenic purpura and normal subjects.

In the present study, although the mean platelet count in peripheral blood was significantly lower in patients with chronic liver disease than that in the control subjects, the mean serum platelet-derived growth factor level in 
patients with chronic liver disease was not lower than that in control subjects (fig. la). Jorgensen et al. reported that the mean volume of platelets in patients with chronic liver disease was smaller than that in normal subjects (23). These findings suggest that the amount of platelet-derived growth factor releasable from each platelet is increased and concentrated in patients with chronic liver disease. The mean amount of platelet-derived growth factor released from platelets in patients with chronic liver disease was significantly greater than that in control subjects (fig. 1b). The value significantly correlated with indicators of liver function, such as the serum concentration of pseudocholinesterase and the indocyanine green value in the combined group. Serum pseudocholinesterase activity and indocyanine green clearance rate are known to reflect liver function and are thought to be markers of the progression of liver cirrhosis (10). In this study, we focussed on serum plateletderived growth factor for evaluation of the amount of platelet-derived growth factor released from platelets, instead of measuring the cellular content of platelet-derived growth factor from platelet lysate. Actually, the ratio of platelet-derived growth factor released from the aggregated platelets to cellular platelet-derived growth factor was $0.80 \pm 0.20$ (mean $\pm S D$ ) in 4 healthy volunteers (data not shown). This observation suggests that the majority of cellular platelet-derived growth factor is released at the time of aggregation, and that measurement of serum platelet-derived growth factor reflects the cellular content of platelet-derived growth factor (cf. tab. 2). Moreover, serum platelet-derived growth factor values would reflect the amount of platelet-derived growth factor released from platelets during platelet aggregation at sites of inflammation in the liver in vivo. Although platelet-derived growth factor is known to bind to $\alpha_{2}$-macroglobulin (24) and other plasma proteins, the effect of these binding proteins on our assay system should be minimal, since the plasma levels of platelet-derived growth factor studied were all below the detection limit in our assay system.

Thrombocytopenia is often seen in 'patients with chronic liver disease associated with portal hypertension and/or hypersplenism. The life-span of platelets is shortened and platelets are assumed to be consumed in the liver in chronic liver diseases (18). Several types of in vivo studies have demonstrated that fat-storing cells play a central role in liver fibrogenesis $(11-13)$. Recent studies have also shown that platelet-derived growth factor stimulates proliferation of cultured fat-storing cells and synthesis of matrix components by fat-storing cells (14-17). However, the source of platelet-derived growth factor in liver fibrogenesis is uncertain. In patients with idiopathic pulmonary fibrosis, alveolar macrophages release a large amount of platelet-derived growth factor (25). In chronic liver diseases, it is possible that activated macrophages, including Kupffer cells, and/or platelets, which accumulate in hepatic inflammation $(18,26)$, release plateletderived growth factor. These findings suggest that the large amount of platelet-derived growth factor released by platelet activation in patients with chronic liver disease may be involved in the pathophysiology of chronic liver diseases as a local factor.

Further studies are required on the mechanism of increase of platelet-derived growth factor in platelets in patients with chronic liver disease, on whether plateletderived growth factor is released at inflammatory sites in the liver in chronic liver disease, and on whether or not platelet-derived growth factor aggravates the progression of chronic liver diseases in vivo.

Tab. 2 Platelet-derived growth factor concentrations in serum and platelet lysate in 4 healthy volunteers

\begin{tabular}{|c|c|c|c|c|c|c|c|c|}
\hline \multirow[t]{2}{*}{ Case } & \multirow[t]{2}{*}{$\begin{array}{l}\text { Haema- } \\
\text { tocrit }\end{array}$} & \multicolumn{2}{|c|}{$\begin{array}{l}\text { Platelet count } \\
\left(10^{9} / 1\right)\end{array}$} & \multicolumn{2}{|c|}{$\begin{array}{l}\text { Platelet-derived } \\
\text { growth factor } \\
(\mu \mathrm{g} / \mathrm{l})\end{array}$} & \multicolumn{2}{|c|}{$\begin{array}{l}\text { Platelet-derived } \\
\text { growth factor/ } \\
\text { platelets } \\
\text { (ng/ } 10^{9} \text { platelets) } \\
\text { calculated from }\end{array}$} & \multirow{2}{*}{$\begin{array}{l}\text { Ratio of platelet- } \\
\text { derived growth } \\
\text { factor/platelets } \\
\text { calculated from } \\
\text { serum to that } \\
\text { calculated from } \\
\text { platelet lysate }\end{array}$} \\
\hline & & $\begin{array}{l}\text { Whole } \\
\text { blood }\end{array}$ & $\begin{array}{l}\text { Platelet } \\
\text { lysate }\end{array}$ & Serum & $\begin{array}{l}\text { Platelet } \\
\text { lysate }\end{array}$ & Serum & $\begin{array}{l}\text { Platelet } \\
\text { lysate }\end{array}$ & \\
\hline $\begin{array}{l}1 \\
2 \\
3 \\
4\end{array}$ & $\begin{array}{l}0.48 \\
0.41 \\
0.40 \\
0.39\end{array}$ & $\begin{array}{l}149 \\
162 \\
111 \\
341\end{array}$ & $\begin{array}{r}93 \\
151 \\
102 \\
254\end{array}$ & $\begin{array}{l}3.7 \\
4.7 \\
4.4 \\
7.2\end{array}$ & $\begin{array}{l}1.9 \\
4.1 \\
2.7 \\
3.2\end{array}$ & $\begin{array}{l}12.9 \\
17.4 \\
23.9 \\
12.8\end{array}$ & $\begin{array}{l}20.6 \\
26.8 \\
26.5 \\
12.5\end{array}$ & $\begin{array}{l}0.63 \\
0.65 \\
0.90 \\
1.03\end{array}$ \\
\hline $\begin{array}{l}\text { Mean } \\
\pm S D\end{array}$ & $\begin{array}{r}0.42 \\
\pm 0.04\end{array}$ & $\begin{array}{r}191 \\
\pm 102\end{array}$ & $\begin{array}{r}150 \\
\pm 74\end{array}$ & $\begin{array}{r}5.0 \\
\pm 1.5\end{array}$ & $\begin{array}{r}3.0 \\
\pm 0.9\end{array}$ & $\begin{array}{r}16.8 \\
\pm 5.2\end{array}$ & $\begin{array}{r}21.6 \\
\pm 6.7\end{array}$ & $\begin{array}{r}0.80 \\
\pm 0.20\end{array}$ \\
\hline
\end{tabular}




\section{References}

1. Johnsson, A., Heldin, C. H., Westermark, B. \& Wasteson, $\AA$. (1982) Platelet-derived growth factor: Identification of constituent polypeptide chains. Biochem. Biophys. Res. Commun. 104, 66-74.

2. Kaplan, D. R., Chao, F. C., Stiles, C. D., Antoniades, H. N. \& Scher, C. D. (1979) Platelet alpha-granule proteins on release and subcellular localization. Blood 53, 1043-1052.

3. Kaplan, K. L., Broekman, M. J., Chernoff, A., Lesznik, G. R. \& Drillings, M. (1979) Platelet alpha-granules contain a growth factor for fibroblasts. Blood 53, 604-618.

4. Gerrard, J. M., Phillips, D. R., Rao, G. H. R., Plon, E. F., Walc, P. A., Ross, R., Harker, L. A. \& White, J. G. (1980) Biochemical studies of two patients with the gray platelet syndrome. J. Clin. Invest. 66, 102-109.

5. Kohler, N. \& Lipton, A. (1974) Platelets as a source of fibroblast growth-promoting activity. Exp. Cell Res. 87, 297-301.

6. Antoniades, H. N. \& Scher, C. D. (1977) Radioimmunoassay of a human serum growth factor for balb/c-3T3 cells: Derivation from platelets. Proc. Natl. Acad. Sci. USA 74, 19731977.

7. Ross, R., Glomset, J., Kariya, B. \& Harker, L. (1974) A platelet-dependent serum factor that stimulates the proliferation of arterial smooth muscle cells in vitro. Proc. Natl. Acad. Sci. USA $7 I, 1207-1210$.

8. Westermark, B. \& Wasteson, A. (1976) Platelet factor stimulating human normal glial cells. Exp. Cell Res. 98, 170-174.

9. Ross, R. \& Glomset, J. A. (1976) The pathogenesis of atherosclerosis. N. Engl. J. Med. 295, 369-377, 420-425.

10. Schiff, L. \& Schiff, E. R. (1987) Disease of the liver, 6th ed., pp. 199-200, Lippincot Co., Philadelphia.

11. Kent, G., Gay, S., Inouye, T., Bahy, R., Minick, O. T. \& Popper, H. (1974) Vitamin A-containing lipocytes and formation of type III collagen in liver injury. Proc. Natl. Acad. Sci. USA $73,3719-3722$.

12. Mitano, Y., Hasumura, Y. \& Takeuchi, J. (1983) The role of fat-storing cells in Disse space fibrogenesis in alcoholic liver disease. Hepatology 3, 559-566.

13. Okanoue, T., Burgie, E. J. \& French, S. W. (1983) The role of the Ito cell in perivenular and intralobular fibrosis in alcoholic hepatitis. Arch. Pathol. Lab. Med. 107, 459-463.

14. Friedman, S. L. \& Arthur, M. J. P. (1989) Activation of cultured rat hepatic lipocytes by Kupffer cell conditioned medium. Direct enhancement of matrix synthesis and stimulation of cell proliferation via induction of platelet-derived growth factor receptors. J. Clin. Invest. 84, 1780-1785.

15. Pinzani, M., Gesualdo, L., Sabbah, G. M. \& Abboud, H. E. (1989) Effects of platelet-derived growth factor and other polypeptide mitogens on DNA synthesis and growth of cultured rat liver fat-storing cells. J. Clin. Invest. 84, 1786-1793.

16. Heldin, P., Pertoft, H., Nordlinder, H., Heldin, C. H. \& Laurent, T. C. (1991) Differential expression of platelet-derived growth factor and receptors on fat-storing cells and endothelial cells of rat liver. Exp. Cell Res. 193, 364-369.

17. Bachem, M. G., Melchior, R. \& Gressner, A. M. (1989) The role of thrombocytes in liver fibrogenesis: Effects of platelet lysate and thrombocyte-derived growth factors on the mitogenic activity and glycosaminoglycan synthesis of cultured rat liver fat storing cells. J. Clin. Chem. Clin. Biochem. 27, $555-565$

18. Stein, S. F. \& Harker, L. A. (1982) Kinetic and functional studies of platelets, fibrinogen, and plasminogen in patients with hepatic cirrhosis. J. Lab. Clin. Med. 99, 217-230.

19. Shiraishi, T., Morimoto, S., Itoh, K., Sato, H., Sugihara, K., Onishi, T. \& Ogihara, T. (1989) Radioimmunoassay of human platelet-derived growth factor using monoclonal antibody toward a synthetic 73-97 fragment of its B-chain. Clin. Chim. Acta $184,65-74$.

20. Kuo, G., Choo, Q. L., Alter, H. J., Gitnick, G. L., Redeker, A. G., Purcell, R. H., Miyamura, T., Dienstag, J. L., Alter, M. J., Stevens, G. E., Tegtmeier, G. E., Bonino, F., Colombo, M., Lee, W. S., Kuo, C., Berger, K., Shuster, J. R., Overby, L. R., Bradley, D. W. \& Houghton, M. (1989) An assay for circulating antibodies to a major etiologic virus of human non- $A$, nonB hepatitis. Science 244, 362-364.

21. Bowen-Pope, D. F., Malpass, T. W., Foster, D. M. \& Ross, R. (1984) Platelet derived growth factor in vivo: Levels, activity and rate of clearance. Blood $64,458-469$.

22. Morimoto, S., Shiraishi, T., Fukuo, K., Koh, E., Kitano, S., Yasuda, O., Tamatani, M. \& Ogihara, T. (1992) Effects of ticlopidine on PDGF release from platelets. Cur. Ther. Res. 52, $382-385$

23. Jørgensen, B., Fisher, E., Ingerberg, S., Hollander, N., RingLarsen, H. \& Henriksen, J. H. (1984) Decreased blood volume and count in patients with liver disease. Scand. J. Gastroenterol. 19, 492-496. :

24. Huang, J. S., Huang, S. S. \& Deuel, T. F. (1984) Specific covalent binding of platelet-derived growth factor to human plasma $\alpha_{2}$-macroglobulin. Proc. Natl. Acad. Sci. USA 81, $342-346$

25. Martinet, Y., Rom, W. N., Grotendorst, G. R., Martin, G. R. \& Crystal, R. G. (1987) Exaggerated spontaneous release of platelet-derived growth factor by alveolar macrophages from patients with idiopathic pulmonary fibrosis. N. Engl. J. Med. 317, 202-209.

26. Ogawa, K., Suzuki, J., Narasaki, M. \& Mori, M. (1985) Healing of focal injury in the rat liver. Am. J. Pathol. 119, 158167.

Tsunehito Shiraishi M.D.

Department of Geriatric Medicine

Osaka University Medical School

Yamadaoka, Suita, Osaka 565

Japan 
